\title{
Stress reaction in crayfish: chlorides help to withstand stress in high nitrite concentration conditions - preliminary study
}

\author{
P. Kozák ${ }^{(1)}$, T. Policar ${ }^{(1)}$, V. Pavlovich Fedotov(2) ${ }^{(2 .}$ Vladimirovna Kuznetsova(2), \\ M. Buřič ${ }^{(1)}$, A. Kouba ${ }^{(1)}$, I. Kuklina ${ }^{(1)}$, S. Viktorovich Kholodkevich ${ }^{(2)}$
}

Received November 24, 2010

Revised February 19, 2011

Accepted February 28, 2011

Key-words:

Astacus leptodactylus, cardiac activity, heart rate, salinity, stress reaction

\section{ABSTRACT}

\begin{abstract}
A non-invasive method of recording cardiac activity (heart rate - HR) and stress reaction (stress index - SI) was used to understand the immediate and ongoing stress reaction of crayfish to the chemical stimuli. This method detects changes in the shape and amplitude parameters of the response to the stress factors, which characterized the crayfish functional state. Experimental animals (Astacus leptodactylus) were divided to the two groups with $\left(400 \mathrm{mg} \cdot \mathrm{L}^{-1} \mathrm{Cl}^{-}\right)$and without added chlorides and then exposed to a stepwise increased level of nitrite to the final (sublethallethal) concentration of $60 \mathrm{mg} \cdot \mathrm{L}^{-1} \mathrm{~N}-\mathrm{NO}_{2}^{-}$within 24 hours. The course of crayfish reaction was evident and provided information about their reaction to the sublethal-lethal concentration over time. As expected, a less prominent stress reaction was detected in the group with chlorides. The non-invasive method successfully evaluated the sensing of chemical stimuli in water through HR and SI changes.
\end{abstract}

\section{RÉSUMÉ}

Réaction au stress chez l'écrevisse : les chlorures aident à résister au stress dans des conditions de fortes concentrations en nitrite - étude préliminaire

Mots-clés :

Astacus leptodactylus, activité cardiaque, rythme cardiaque, salinité, réaction au stress
Une méthode non-invasive d'enregistrement de l'activité cardiaque (rythme cardiaque - HR) et de réaction au stress (indice de stress - SI) a été utilisée pour comprendre la réaction au stress immédiate et ultérieure de l'écrevisse à des stimuli chimiques. Cette méthode détecte les changements dans la forme et l'amplitude des paramètres de la réponse aux facteurs de stress, qui caractérisent l'état fonctionnel de l'écrevisse. Les animaux de l'expérience (Astacus leptodactylus) ont été divisés en deux groupes avec $\left(400 \mathrm{mg} \mathrm{Cl} \cdot \mathrm{L}^{-1}\right)$ et sans chlorures ajoutés puis exposés à des niveaux croissants par paliers de nitrite jusqu'à la concentration finale (sub-létale-létale) de $60 \mathrm{mg} \cdot \mathrm{L}^{-1} \mathrm{~N}-\mathrm{NO}_{2}^{-}$pendant 24 heures. La réaction de l'écrevisse est évidente et fournit des informations sur les réactions au cours du temps à une concentration sub-létale. Comme escompté, une réaction au stress moins marquée est détectée dans le groupe avec des chlorures. La méthode noninvasive a déterminé correctement l'impact du stimulus chimique de l'eau par les changements de HR et SI.

(1) University of South Bohemia in České Budějovice, Faculty of Fisheries and Protection of Waters, South Bohemian Research Center of Aquaculture and Biodiversity of Hydrocenoses and Research Institute of Fish Culture and Hydrobiology, Zátiší 728/II, CZ-389 25 Vodňany, Czech Republic, kozak@vurh.jcu.cz

(2) St. Petersburg Scientific Research Centre for Ecological Safety, Laboratory of Experimental Ecology of Aquatic Systems, Korpusnaja str. 18, Saint-Petersburg 197110, Russia 


\section{INTRODUCTION}

Toxicity tests usually describe a direct impact of several chemicals on model organisms. The results then express the concentration of a given chemical which caused mortality of tested organisms in a limited time period (Buikema et al., 1982). Nevertheless, much lower (sublethal) concentrations of a chemical could influence the physiological and functional state or behaviour of treated organisms (Kleerekoper, 1976; Schober and Lampert, 1977; Vernberg et al., 1977). Sublethal poisoning may be detectable after a longer time period or even be unnoticeable. Moreover, it may be difficult to detect stress reactions in such cases. Several invasive and non-invasive techniques could be used to evaluate the physiological state of fish (e.g. Kane et al., 2004, 2005) and crayfish (e.g. Bierbower and Cooper, 2009). Both of techniques give accordingly good results. Invasive monitoring is based on method of electrocardiography and uses crayfish as measuring device including animal directly to the measuring circuit (Bierbower and Cooper, 2009). But transduction of physiological data involved invasive procedures such as electrode implantation, which increase physiological disturbance such as unneeded rising of heart rate (Aagaard et al., 1991). One of the non-invasive methods (used in our study) based on the evaluation of the physiological state by measurements of heart rate and cardiac activity patterns was developed for such purposes by Kholodkevich et al. (2007). Heart rate and cardiac activity patterns are the key indicators of the condition of tested organisms and can be expressed as stress dependent factors. These measurements are included in all general clinical assessments in medical science (Swash and Mason, 1984) and are therefore used also for the stress index calculation (Kholodkevich et al., 2008). At present, data regarding fish or crayfish stress reactions to sublethal-lethal levels of poisoning are often lacking. The non-invasive method of detection of heart rate and stress reaction could open a new window of knowledge in toxicology and biomonitoring. It is supposed that crayfish are capable to react quickly to any chemical changes by a stress reaction rather than toxicity thresholds resulting in death of specimens. Numerous authors have found heart rate to be a useful indicator of changes in physiological state, even in crustacean, molluscs and fish (e.g. Depledge and Andersen, 1990; Kholodkevich et al., 2008).

Nitrites $\left(\mathrm{NO}_{2}^{-}\right)$are usually found together with nitrates and ammonia in water. Ammonia $\left(\mathrm{NH}_{3}\right)$ is considered one of the most important contaminants in aquatic environment because of its toxic nature and ubiquity in surface water system. It is discharged into the environment in large quantities from industrial, municipal and agricultural sources (Bloxham et al., 1999). In aquatic ecosystems, nitrite concentrations are elevated by pollution with nitrogenous wastes and imbalances in bacterial nitrification and denitrification processes (Eddy and Williams, 1987). The average concentration of $\mathrm{N}-\mathrm{NO}_{2}^{-}$in ground water ranges from 0.004 to $0.179 \mathrm{mg} \cdot \mathrm{L}^{-1}$. Higher concentrations (more than $1 \mathrm{mg} \cdot \mathrm{L}^{-1}$ ) occur in wastewater (Pitter, 1999) and in intensive aquaculture recirculating systems usually in newly activated biofilters (Masser et al., 1999). In fish, nitrites are absorbed by the gills and oxidize the iron in the haemoglobin molecules to methemoglobin. The result of nitrite poisoning is methaemoglobinemia caused by a reduction in the blood oxygen carrying ability (Svobodová et al., 2005). It is likely that a similar type of reaction to that occurring with the iron of haemoglobin also occurs with the copper in crustacean hemocyanin (Colt and Armstrong, 1981). Nitrites have an affinity for the active chloride uptake mechanism by chloride cells in the gills. Chloride cells excrete ammonia or $\mathrm{H}^{+}$ions for $\mathrm{Na}^{+}$and bicarbonate $\left(\mathrm{HCO}_{3}^{-}\right)$for $\mathrm{Cl}^{-}$(Love, 1980). Nitrites thus have an affinity to $\mathrm{Cl}^{-} / \mathrm{HCO}_{3}^{-}$exchange. Part of chloride demand is replaced by $\mathrm{NO}_{2}^{-}$when available in water. The higher concentration of chlorides therefore protects fish against the toxic impact of nitrite via the competition between chloride and nitrite ions transporting across the gill membrane (Jensen, 2003). The positive effect of chloride on tolerance to nitrites has been demonstrated in other studies in fish (Hilmy et al., 1987; Atwood et al., 2001; Huertas et al., 2002; Fuller et al., 2003; Taveres and Boyd, 2003) and crayfish (Beitinger and Huey, 1981; Jeberg and Jensen, 1994; Kozák et al., 2005).

This study was concerned with 1) a preliminary testing of the reactivity of crayfish to the common chemical, nitrite, to gain information about sensitiveness to an increasing level of chemical stimuli up to the sublethal-lethal concentration and 2) to evaluate if chlorides could 
help crayfish to withstand stress in high nitrite concentration conditions. The sensitivity of a non-invasive method for heart rate and stress index monitoring was also evaluated. This study can offer some suggestions and recommendations for future research of heart rate and stress monitoring in crayfish or fish.

\section{MATERIAL AND METHODS}

The experiment was conducted in the Laboratory of Experimental Ecology of Aquatic Systems, Saint-Petersburg Scientific Research Center for Ecological Safety, Russia.

\section{$>$ EQUIPMENT}

A fibre-optic method originally developed for recording cardiac activity of Crustacea (Decapoda) and Mollusca was used (Fedotov et al., 2000; Kholodkevich et al., 2008). The optical signal modulated by the heart of the tested animal contains information on cardiac activity which is processed by a personal computer (for more details see Kholodkevich et al., 2008) (Figure 1). The results create a photoplethysmogram, which can be further analyzed by various mathematical and statistical methods. The variation pulsometry method was used to study the distribution of cardiac intervals, and analyze relationships between its shape and the functioning of the cardiac system (Kholodkevich et al., 2008) (Figure 2). For this method the following characteristics were chosen as biomarkers: heart rate (HR), and stress-index $(\mathrm{SI})$, which is defined by the formula:

$$
\mathrm{SI}=1 /\left(2 * \mathrm{CI}_{\mathrm{m}}{ }^{*} \mathrm{SD}^{2}\right),
$$

where $\mathrm{Cl}_{\mathrm{m}}=$ mean cardiac interval, which is related to $\mathrm{HR}$, with $\mathrm{HR}=60 / \mathrm{Cl}_{\mathrm{m}}$; $\mathrm{SD}=$ standard deviation of heart rate (Kholodkevich et al., 2007, 2008).

\section{> ANIMALS AND EXPERIMENTAL CONDITIONS}

Narrow-clawed crayfish originating from Sevan Lake (Armenia) were used in the experiment. The animals were acclimatized to the controlled conditions for three weeks before the experiment. They were kept in a trough $(2.5 \times 0.5 \times 0.3 \mathrm{~m})$ with shelters in a recirculating system. During the experiment, each crayfish was maintained in a separate 5 -liter aquarium with a shelter, which allowed the crayfish to stay inside (Figure 3). The water level was set at $15 \mathrm{~cm}$. Crayfish were not fed during the experiment. The non-treated water quality parameters were as follows: temperature $22{ }^{\circ} \mathrm{C}$, oxygen saturation $80-100 \%, \mathrm{pH} 7.5, \mathrm{HCO}_{3}^{-} 32.5 \mathrm{mg} \cdot \mathrm{L}^{-1}$, $\mathrm{SO}_{4}^{2-} 19.3 \mathrm{mg} \cdot \mathrm{L}^{-1}, \mathrm{Cl}^{-} 7.8 \mathrm{mg} \cdot \mathrm{L}^{-1}, \mathrm{Ca}^{2+} 11.3 \mathrm{mg} \cdot \mathrm{L}^{-1}, \mathrm{Mg}^{2+} 2.9 \mathrm{mg} \cdot \mathrm{L}^{-1}, \mathrm{Na}^{2+} 3.3 \mathrm{mg} \cdot \mathrm{L}^{-1}$, $\mathrm{K}^{+} 1.5 \mathrm{mg} \cdot \mathrm{L}^{-1}$. The experiment was performed at the September photoperiod ( $\mathrm{D}: \mathrm{N}=14: 10$ ).

\section{>EXPERIMENTAL DESIGN}

The study was conducted in two groups, with added chlorides $\left(\mathrm{Cl}^{-} ; 400 \mathrm{mg} \cdot \mathrm{L}^{-1}\right)$ and without chlorides. The chloride level of $400 \mathrm{mg} \cdot \mathrm{L}^{-1}$ was chosen as relatively safe for crayfish (Kozák et al., 2009) and helpful against a negative impact of nitrites (Kozák et al., 2005). Each group consisted of three adult males, with total length $(T L)=131.3 \pm 3.5 \mathrm{~mm}$, carapace length $(\mathrm{CL})=$ $70.7 \pm 2.2 \mathrm{~mm}$ and weight $(\mathrm{w})=63.7 \pm 4.1 \mathrm{~g}$ in the chlorides group, and TL $=130.7 \pm 3.9 \mathrm{~mm}$; $\mathrm{CL}=71.0 \pm 2.6 \mathrm{~mm}$ and $\mathrm{w}=70.3 \pm 5.5 \mathrm{~g}$ in the group without chlorides, respectively. One monitoring system at full capacity monitored all six treated specimens during the 24 hours period of treatment.

Animals were stocked in aquaria for acclimation in the evening before the day of the experiment. The concentration of $60 \mathrm{mg} \mathrm{N}-\mathrm{NO}_{2}^{-} \cdot \mathrm{L}^{-1}$ was chosen as a possible sublethal-lethal 


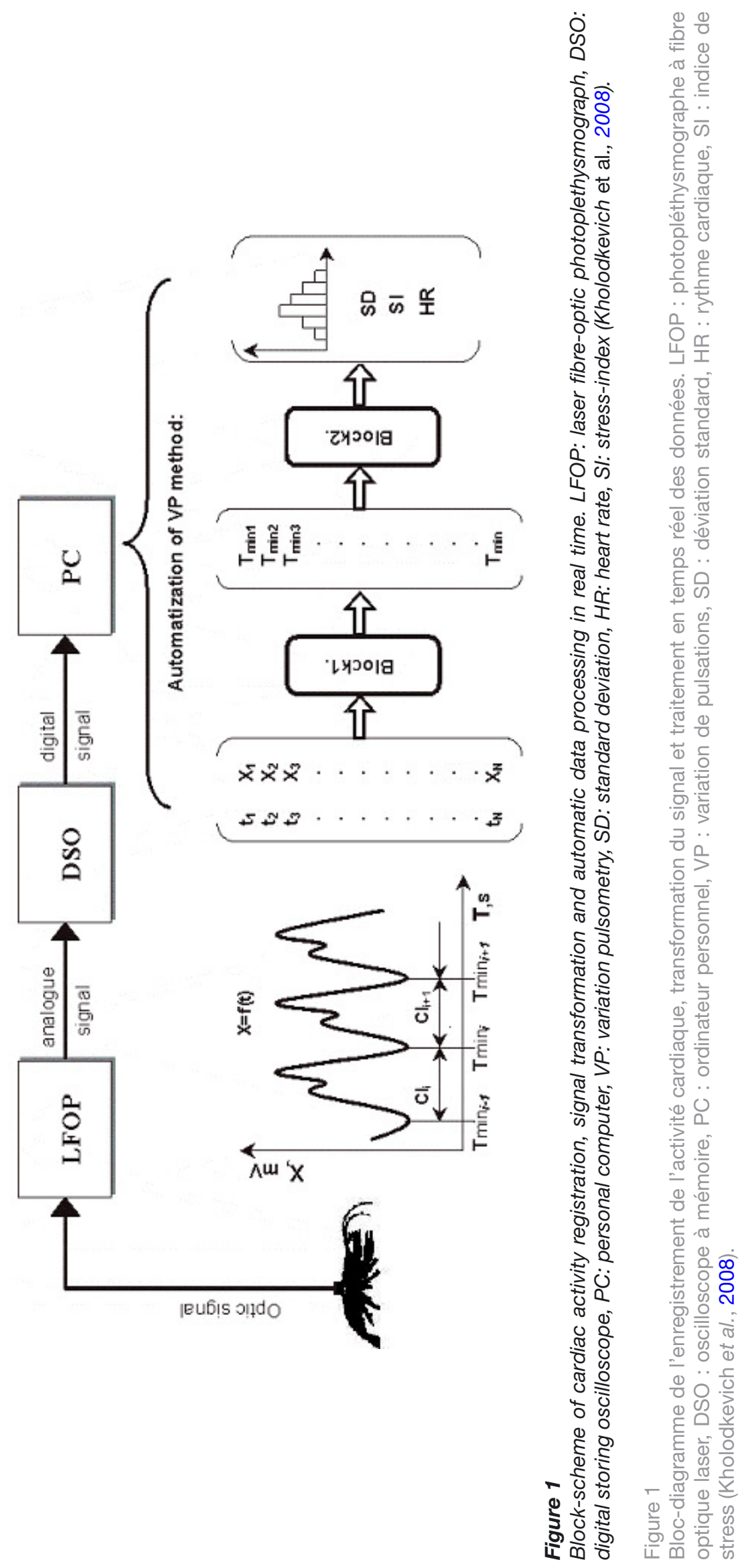




\section{Cardiac intervals distribution}

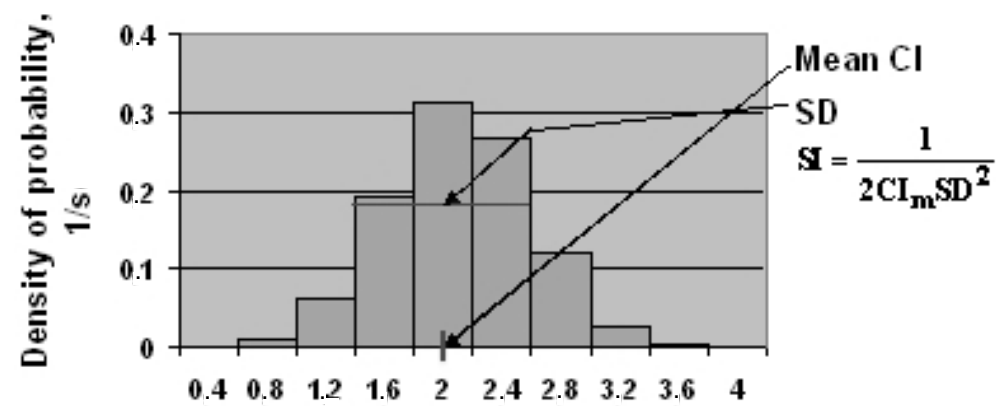

Time, s

\section{Figure 2}

Variation pulsometry method to study relations between cardiac system functioning and the cardiac intervals distribution law (Kholodkevich et al., 2008).

\section{Figure 2}

Méthode de variation de pulsations pour étudier les relations entre le fonctionnement cardiaque et la loi de distribution des phases d'activité cardiaque (Kholodkevich et al., 2008).

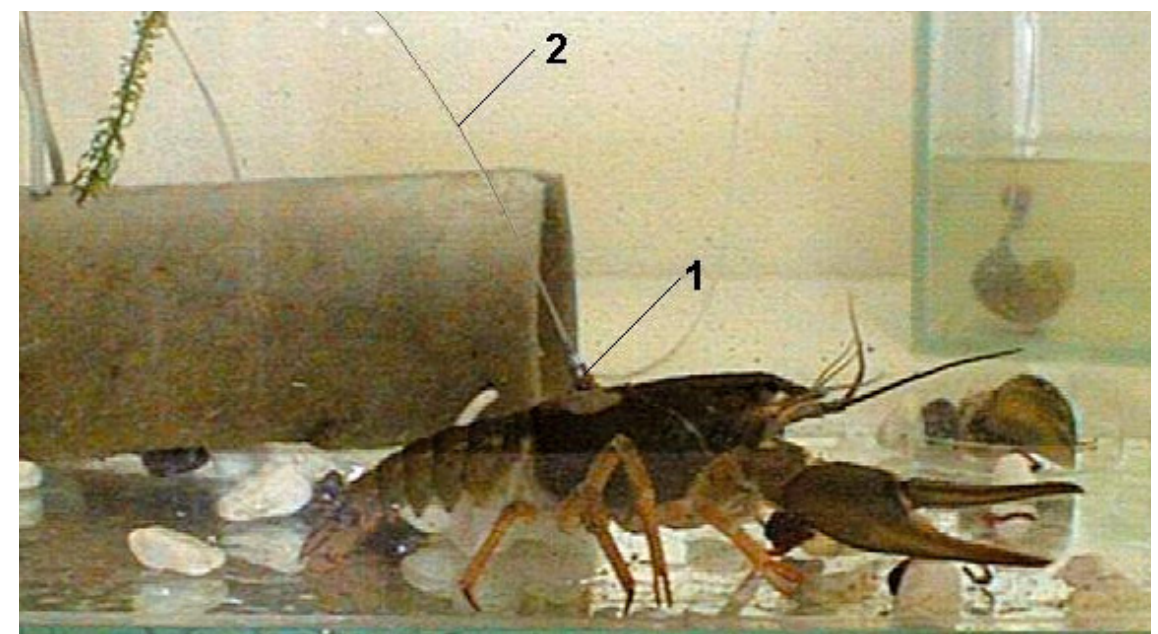

\section{Figure 3}

Narrow-clawed crayfish (Astacus leptodactylus) in 5-L aquarium with a shelter, which allowed the crayfish with sensor (1) and fibre (2) attached to stay inside (Kholodkevich et al., 2008).

\section{Figure 3}

Écrevisse à pattes grêles (Astacus leptodactylus) dans un aquarium de 5 L avec un abri qui accueille l'écrevisse équipée de senseur (1) et fibre (2) de (Kholodkevich et al., 2008).

concentration for crayfish in the short time exposure according to the literature and previous experiments with Orconectes limosus (Kozák et al., 2005). The relevant amounts of $\mathrm{Cl}^{-}$, dissolved in $100 \mathrm{~mL}$ of water and the first concentration of nitrite $\left(3.75 \mathrm{mg} \mathrm{N}-\mathrm{NO}_{2}^{-} \cdot \mathrm{L}^{-1}\right)$, were applied together to aquaria. Nitrite concentrations were increased every two hours from the initial level of $3.75 \mathrm{mg} \mathrm{N}-\mathrm{NO}_{2}^{-} \cdot \mathrm{L}^{-1}$ through concentrations of $7.5,15,30 \mathrm{mg} \mathrm{N}-\mathrm{NO}_{2}^{-} \cdot \mathrm{L}^{-1}$, to the final concentration of $60 \mathrm{mg} \mathrm{N}-\mathrm{NO}_{2}^{-} \cdot \mathrm{L}^{-1}$. Crayfish exposure in each nitrite concentration therefore lasted for two hours. Crayfish were then exposed to the highest concentration for 16 hours. Crayfish were then placed in fresh water without any additional chlorides or nitrites for one day. Samples of water for chemical analysis were taken regularly from each concentration. 


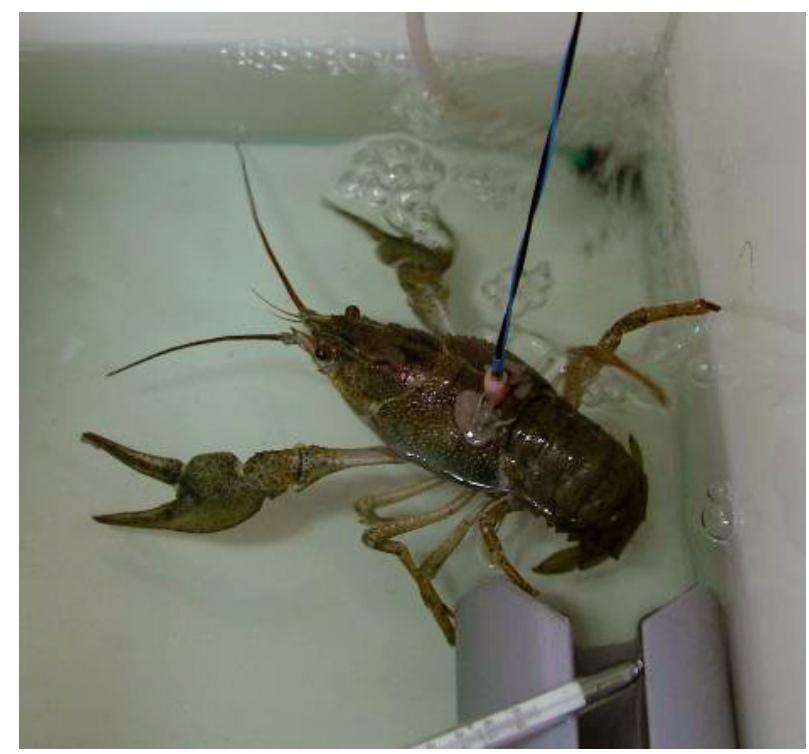

\section{Figure 4}

The hanging of crayfish - crayfish is hanged on wire above the floor, provided to evaluate their physiological stage.

\section{Figure 4}

Écrevisse suspendue au-dessus du fond pour évaluer son état physiologique.

\section{> DATA ANALYSIS}

Data were edited and examined using ANOVA for repeated measurements with Tukey post-hoc test in program Statistica 9.0 (StatSoft., Inc.). Data are presented as means \pm SE.

\section{RESULTS AND DISCUSSION}

We demonstrated the effectiveness of the non-invasive method for monitoring cardiac activity of crayfish exposed to the sublethal-lethal nitrite concentration. Crayfish reaction to excess nitrite was detectable (Figure 5). It can be presumed that a similar type of reaction as known in fish, i.e. accumulation of nitrites resulting in subsequent methaemoglobinemia (Kroupová et al., 2005; Svobodová et al., 2005), occurs in copper of crustacean hemocyanin (Colt and Armstrong, 1981; Rainbow, 2002; Kouba et al., 2010). We found a difference in both heart rate and stress index and the "chloride" group could be distinguished on the basis of obtained data. The stress index (SI) was already found to be elevated from the 2nd tested $\mathrm{N}-\mathrm{NO}_{2}^{-}$level $\left(7.5 \mathrm{mg} \cdot \mathrm{L}^{-1}\right)$ in the group without chlorides. Reactions in crayfish to the treatment with increased chlorides were observed from the N-NO of reactions to increasing nitrite levels, in both $\mathrm{SI}$ and $\mathrm{HR}$, was significantly influenced by the presence of chlorides. Heart rates of animals without added salt presented fluctuating values independently of nitrite exposure as a probable impact of their toxicity. Regarding heart rate, the loss of its circadian rhythmicity has been presented as a potential early warning indicator for mortality in freshwater crab Potamon potamios and noble crayfish (Astacus astacus) after toxication (Styrishave and Depledge, 1996).

Generally, crayfish in the group without chlorides showed more distinct reactions. Such status is presumably related to maintaining homeostasis in both crayfish and fish (Maetz, 1971; Wheatly and Gannon, 1995), and the related competition of chloride and nitrite ions in the gill chloride cells. Crayfish in both groups were insensible and "near to death" at the end of observations, but with different stress reactions (Figures 4, 6-8). Such harmful effects are not surprising when we consider that values of $96 \mathrm{hLC} 50$ for $\mathrm{N}^{-\mathrm{NO}_{2}^{-}}$usually range from 0.66 
P. Kozák et al.: Knowl. Managt. Aquatic Ecosyst. (2011) 401, 05
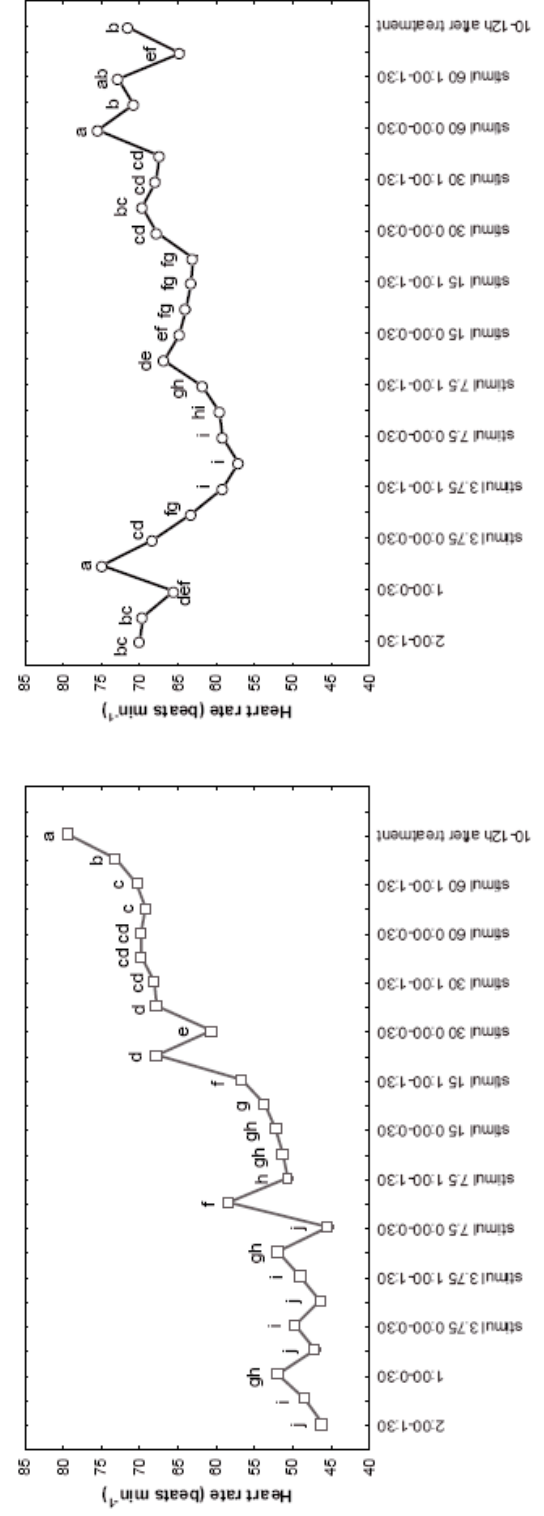

है

잉

은

$\frac{1}{\partial}$

일

$\stackrel{2}{2}$

ㄱㅇㅇ

O

o以

हा

○ঙ

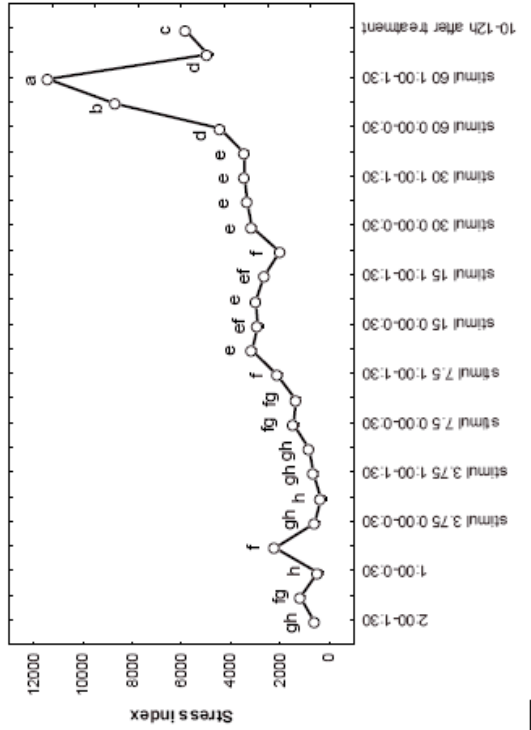

政

응 응

อ II

$\pm$

ఏ ऐ

Q

ब出

든은

ปิ ญิ

告

일

๑

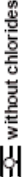

突

ฮ

हा

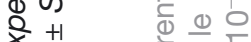

(1) 过

क 눙

워

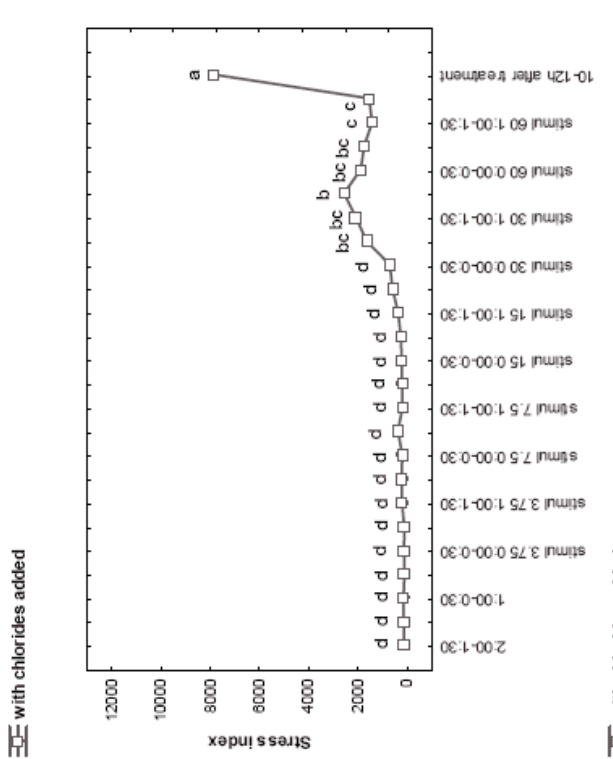

ช

en

(๘)

क ष

क

(1)

ब ब

(1) 


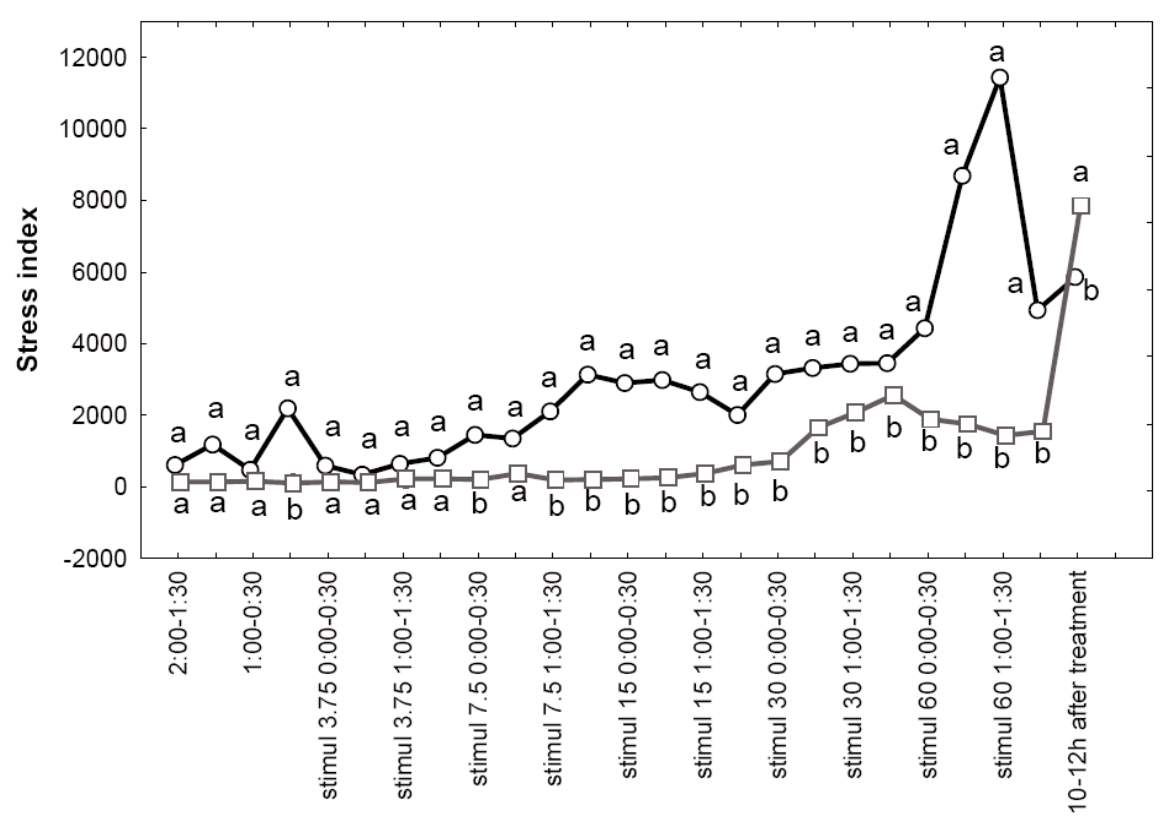

조 without chlorides 포

\section{Figure 6}

The comparison of crayfish stress index at different nitrite levels between group with (400 $\left.\mathrm{mg} \mathrm{Cl}^{-} \cdot \mathrm{L}^{-1}\right)$ and without an addition of chlorides. Data are presented as mean $\pm S E$. Different superscripts differ at $\alpha=0.05$ (ANOVA, $\left.F=238.7, P<10^{-6}\right)$.

\section{Figure 6}

Comparaison des indices de stress de l'écrevisse soumise à différentes concentrations de nitrite entre le groupe dans l'eau avec chlorures $\left(400 \mathrm{mg} \mathrm{Cl}^{-} \cdot \mathrm{L}^{-1}\right)$ et celui sans addition de chlorures. Les données sont des moyennes avec écart-type. Les différentes lettres diffèrent au niveau $\alpha=0,05$ (ANOVA, $F=238,7$; $\left.P<10^{-6}\right)$.

to $200 \mathrm{mg} \cdot \mathrm{L}^{-1}$ in freshwater fish, or commonly between 8.5 and $15.4 \mathrm{mg} \cdot \mathrm{L}^{-1}$ for crustaceans (Boyd, 1990 in Rouse et al., 1995). In general, the N-NO- concentration of $60 \mathrm{mg} \cdot \mathrm{L}^{-1}$ was critical for both groups. However, crayfish were placed into fresh water for 24 hours following nitrite exposure. While all crayfish from the group without chlorides died within this time, the other group was capable of fast recovery under fresh water conditions and survived. Chloride presence therefore enabled crayfish to withstand and survive very high nitrite concentration.

On the other hand, toxic chemicals such as nitrite have visible negative effects when exceeded - the danger of direct death of animals. However, sublethal effects of nitrites or other chemicals should not be underrated. It is known that elevated concentrations of nitrites results in reduced fitness of animals because of ionic imbalance of extra cellular fluids or increased energy costs in the process of maintaining additional transport sites (Harris and Coley, 1991). Rouse et al. (1995) presented that 24-hour exposure to nitrite concentrations of $0.4 \mathrm{mg} \cdot \mathrm{L}^{-1}$ and $0.6 \mathrm{mg} \cdot \mathrm{L}^{-1}$ decreased subsequent growth of redclaw crayfish (Cherax quadricarinatus) by $17 \%$ and $67 \%$ and increased mortality by $5 \%$ and $48 \%$, respectively. It can be expected that it is a result of the stress reaction caused by nitrite treatment.

Finally, we can safely claim that the presented method of stress monitoring can and should be used to fill knowledge gaps about sublethal effect of toxicants in aquatic environment and give real levels of chemicals which do not cause any disruptions or deteriorations in health, behaviour or chemical communication of cultured or wild (free living) organisms. 
P. Kozák et al.: Knowl. Managt. Aquatic Ecosyst. (2011) 401, 05

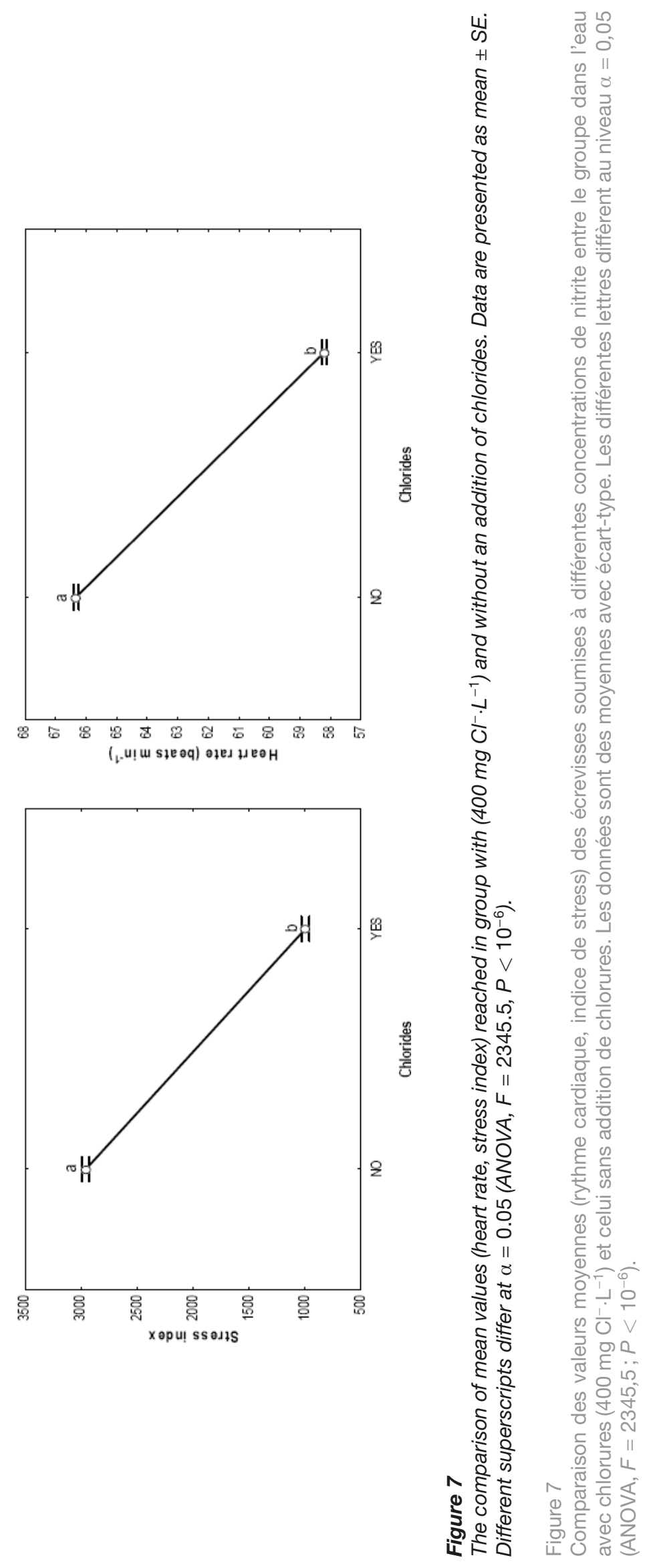



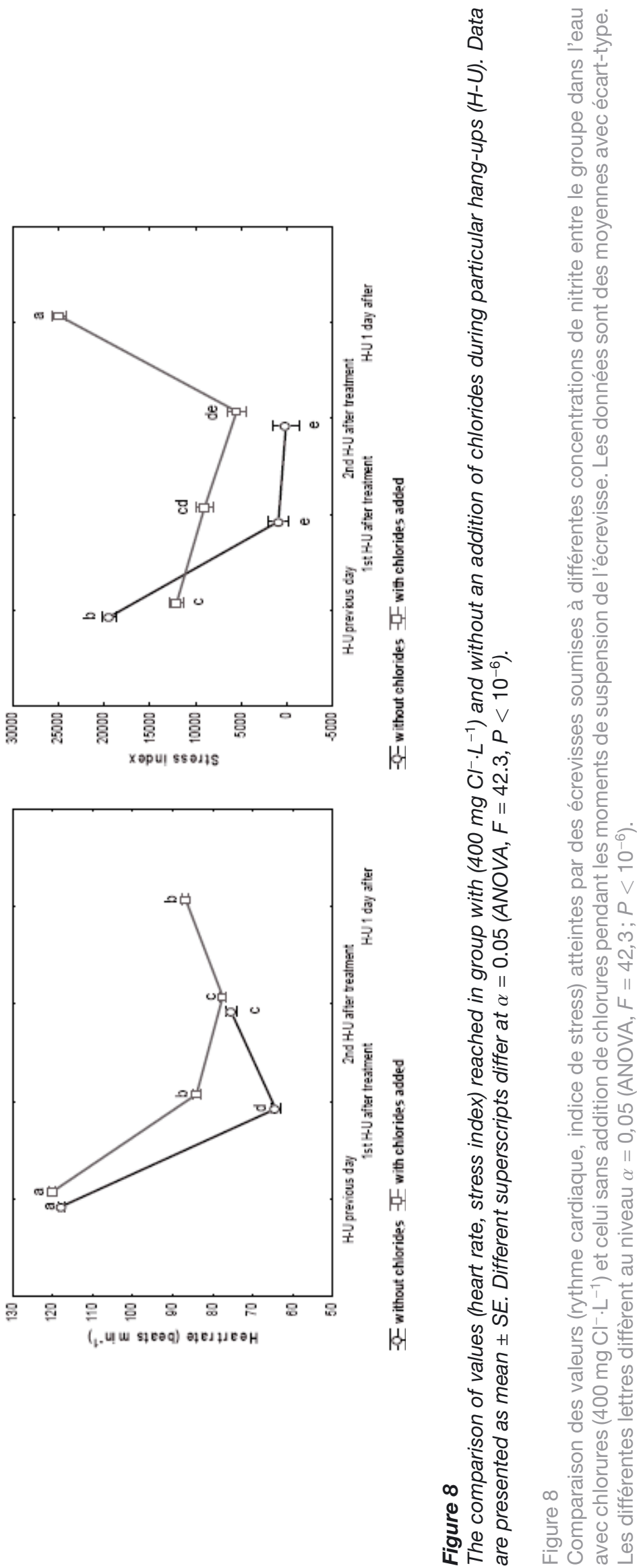


\section{ACKNOWLEDGEMENTS}

This investigation was financially supported by the Ministry of Education, Youth, and Sports of the Czech Republic (MSM6007665809, CENAKVA CZ.1.05/2.1.00/01.0024 and ME 10125), and by the Grant Agency of the University of South Bohemia (047/2010/Z). We also thank Julian Reynolds for English correction of this manuscript.

\section{REFERENCES}

Aagaard A., Andersen B.B. and Depledge M.H., 1991. Simultaneous monitoring of physiological and behavioral activity in marine organisms using non-invasive, computer-aided techniques. Mar. Ecol. Prog. Ser., 73, 277-282.

Atwood H.L., Fontenot Q.C., Tomasso J.R. and Isely J.J., 2001. Toxicity of nitrite to Nile tilapia: Effect of fish size and environmental chloride. N. Am. J. Aquacult., 63, 49-51.

Beitinger T.L. and Huey D.W., 1981. Acute toxicity of nitrite to crayfish Procambarus simulans in varied environmental conditions. Environ. Pollut. Ser. A, 29, 305-311.

Bierbower S.M., and Cooper R.L., 2009. Measures of heart and ventilatory rates in freely moving crayfish. JoVE, 32.

Bloxham M.J., Worsfold P.J. and Depledge M.H., 1999. Integrated biological and chemical monitoring: in situ physiological responses of freshwater crayfish to fluctuations in environmental ammonia concentrations. Ecotoxicology, 8, 225-231.

Buikema A.L. Jr., Niederlehner B.R. and Cairns J.K. Jr., 1982. Biological monitoring, Part IV - Toxicity testing. Water Res., 16, 239-262.

Colt J. and Armstrong D.A., 1981. Nitrogen toxicity to crustaceans, fish and molluscs. In: Allen L.J. and Kinny E.C. (eds.), Proceedings of the Bio-Engineering Symposium for Fish Culture, Fish Culture Section, Northeast Society of Conservation Engineers, Bethesda, MD, 34-47.

Depledge M.H. and Andersen B.B., 1990. A computer-aided physiological monitoring system for continuous, long-term recording of cardiac activity in selected invertebrates. Comp. Biochem. Physiol. A, $96,473-477$.

Eddy F.B. and Williams E.M., 1987. Nitrites and freshwater fish. Chem. Ecol., 3, 1-38.

Fedotov V.P., Kholodkevich S.V. and Strochilo A.G., 2000. Study of contractile activity of the crayfish heart with the aid of a new non-invasive technique. J. Evol. Biochem. Physiol., 96, 473-477.

Fuller S.A., Henne J.P., Carmichael G.J. and Tomasso J.R., 2003. Toxicity of ammonia and nitrite to the Gila trout. N. Am. J. Aquacult., 65, 162-164.

Harris R.R. and Coley S., 1991. The effect of nitrite on chloride regulation in the crayfish Pacifastacus leniusculus Dana (Crustacea: Decapoda). J. Comp. Physiol. B, 161, 199-206.

Hilmy A.M., El-Domiaty N.A. and Wershana K., 1987. Effect of sodium chloride and calcium chloride on nitrite induced methemoglobinemia in Clarias lazera. Water Air Soil Poll., 33, 57-63.

Huertas M., Gisbert E., Rodriguez A., Williot P. and Castello-Orvay F., 2002. Acute exposure of Siberian sturgeon (Acipenser baeri, Brandt) yearlings to nitrite: median-lethal concentration (LCsub (50)) determination, haematological changes and nitrite accumulation in selected tissues. Aquat. Toxicol., 57, 257-266.

Jeberg M.V. and Jensen F.B., 1994. Extracellular and intracellular ionic changes in crayfish Astacus astacus exposed to nitrite at two acclimation temperatures. Aquat. Toxicol., 29, 65-72.

Jensen F.B., 2003. Nitrite disrupts multiple physiological functions in aquatic animals. Comp. Biochem. Physiol. A, 135, 9-24.

Kane A.S., Salierno J.D., Gipson G.T., Molteno Timothy C.A. and Hunter C., 2004. A video-based movement analysis system to quantify behavioral stress responses of fish. Water Res., 38, 3993-3999.

Kane A.S., Salierno J.D. and Brewer S.K., 2005. Fish models in behavioral toxicology: Automated techniques, updates and perspectives. Methods Aquat. Toxicol., 32, 559-590.

Kholodkevich S.V., Ivanov A.V., Kornienko E.L. and Kurakin A.S., 2007. Method of biological monitoring of the environment (variants) and a system for its performing. RF Patent (Invention) No. 2308720.

Kholodkevich S.V., Ivanov A.V., Kurakin A.S., Kornienko E.L. and Fedotov V.P., 2008. Real time biomonitoring of surface water toxicity level at water supply statios. Environ. Bioindic., 3, 23-34. 
Kleerekoper H., 1976. Effects of sublethal concentrations of pollutants on the behaviour of fish. J. Fish. Res. Board Can., 33, 2036-2039.

Kouba A., Buřič M. and Kozák P., 2010. Bioaccumulation and effects of heavy metals in crayfish: a review. Water Air Soil Poll., 211, 5-16.

Kozák P., Máchová J. and Policar T., 2005. The effect of chloride content in water on the toxicity of sodium nitrite for spiny-cheek crayfish (Orconectes limosus Raf.). Bull. Fr. Pêche Piscic., 376-377, 705-714.

Kozák P., Policar T., Fedotov V.P., Kuznetsova T.V., Buřič M. and Kholodkevich S.V., 2009. Effect of chloride content in water on heart rate in narrow-clawed crayfish (Astacus leptodactylus). Knowl. Managt. Aquatic Ecosyst., 394-395, 08.

Kroupová H., Máchová J. and Svobodová Z., 2005. Nitrite influence on fish: a review. Vet. Med. Czech, $50,461-471$.

Love M.R., 1980. The chemical biology of fishes, Academic Press, New York.

Maetz J., 1971. Fish gills: mechanism of salt transfer in fresh water and sea water. Philos. Trans. R. Soc. Lond. B Biol. Sci., 262, 209-249.

Masser M.P., Rakocy J. and Losordo T.M., 1999. Recirculating aquaculture tank production systems, SRAC Publication No. 452.

Pitter P., 1999. Hydrochemie [Hydrochemistry], VŠCHT, Prague (in Czech).

Rainbow P.S., 2002. Trace metal concentrations in aquatic invertebrates: why and so what? Environ. Pollut., 120, 497-507.

Rouse D.B., Kastner R.J. and Reddy K.S., 1995. Toxicity of ammonia and nitrite to hatchling redclaw crayfish, Cherax quadricarinatus. Freshw. Crayfish, 10, 298-303.

Schober U. and Lampert W., 1977. Effects of sublethal concentrations of the herbicide atrazin on growth and reproduction of Daphnia pullex. Bull. Environ. Contam. Toxicol., 17, 269-277.

Styrishave B. and Depledge M.H., 1996. Evaluation of mercury-induced changes in circadian heart rate rhythms in the freshwater crab, Potamon potamios and the crayfish, Astacus astacus as an early predictor of mortality. Comp. Biochem. Physiol. A, 115, 349-356.

Svobodová Z., Máchová J., Poleszczuk G., Hůda J., Hamáčková J. and Kroupová H., 2005. Nitrite poisoning of fish in aquaculture facilities with water-recirculating systems. Acta Vet. Brno, 74, $129-137$.

Swash M. and Mason S., 1984. Hutchinson's Clinical Methods, 18th edition, Bailliere Tindall, London.

Taveres L.H.S. and Boyd C.E., 2003. Possible effect of sodium chloride treatment on quality of effluents from Alabana channel catfish ponds. J. World Aquacult. Soc, 34, 217-222.

Vernberg W.B., DeCoursey P.J., Kelly M. and Johns D.M., 1977. Effects of sublethal concentrations of cadmium on adult Palaemonetes pugio under static and flow-through conditions. Bull. Environ. Contam. Toxicol., 17, 16-24.

Wheatly M.G. and Gannon A.T., 1995. Ion regulation in crayfish: freshwater adaptations and the problem of molting. Amer. Zool., 35, 49-59. 